Annija Karklina, Dr. iur.

University of Latvia, Latvia

\title{
CONCEPT OF FULLY ELABORATED DRAFT LAW IN THE CONTEXT OF IMPLEMENTING VOTER'S LEGISLATIVE INITIATIVES
}

\begin{abstract}
Summary
Latvia is among the few countries in the world where voters have a right of legislative initiatives or a right to submit draft laws in the Parliament. According to Article 78 of the Constitution of the Republic of Latvia, the electors, in number comprising not less than one tenth of the electorate, have the right to submit a fully elaborated draft of an amendment to the Constitution or a law. However, in order to come as far as submission of a draft law to the Saeima, the voters have to fulfil certain preconditions stipulated in the Law "On National Referendum, Legislative Initiative and European Citizens' Initiative", i.e. set up a group responsible for the draft law and submit to it a fully elaborated draft law or draft amendments to the Constitution to be registered at the Central Election Commission. Given that over time the Central Election Commission has turned down several initiatives of signature collection due to detected shortcomings, the article will discuss the practice established by this institution and analyse conclusions from the case law that apply to content of a fully elaborated draft law.
\end{abstract}

Keywords: totality of citizens, voters' legislative initiative, initiative group, fully elaborated draft law, national referendum, collection of signatures, the Central Election Commission

\section{Introduction}

According to Article 2 (henceforth - Constitution), sovereign power in Latvia belongs to the Latvian people and citizens of the Republic of Latvia having a right to vote exercise this power on behalf of the totality of citizens. Article 64 of the Constitution stipulates that there are two legislative subjects in Latvia Parliament (the Saeima) and the people. Article 78 of the Constitution defines the procedure according to which the voters exercise the right to legislative initiative given to the people: "Electors, in number comprising not less than one tenth of the electorate, have the right to submit a fully elaborated draft of an amendment to the Constitution or of a law to the President, who shall present it to the Saeima. If the Saeima does not adopt it without change as to its content, it shall then be submitted to national referendum." Totality of citizens of Latvia was granted these rights on 7 November 1922, when the Constitution was promulgated and said article has not been amended ever since. Procedure of implementation of voters' legislative initiative has always been regulated in greater detail by the law. Currently it is regulated by the Law "On National Referendum, Legislative Initiative and European 
Citizens' Initiative"' adopted in 1994 (hereinafter - Law), although it has had several significant amendments during the course of its existence.

When the Constitution was elaborated, the Constitutional Assembly initially considered granting voters the initiative rights only concerning amendments of the Constitution, i.e., the version of that time submitted for review envisaged that no less than one fifth of the electorate would be entitled to submit to the President fully elaborated draft amendments to the Constitution $[. .]^{2}$, however, eventually the members of the Constitutional Assembly decided to attribute this right both to laws and amendments to the Constitution. Rights of totality of citizens arising out of Article 78 of the Constitution is an instrument practically used in life. In order to reduce a likelihood of poor quality draft law being submitted, the Saeima adopted amendments to the Law on 8 November 2012, stipulating stricter procedural steps for initiating draft laws by the voters, including introduction of a requirement to specify an initiative group responsible for the draft law (initiative group can be a political party or an association of such, or an association established and registered according to the procedure laid down in Associations and Foundations Law and consisting of at least 10 voters) ${ }^{3}$ and clearly defining competence of the Central Election Commission (henceforth - CEC) in reviewing and registering draft laws for further collection of signatures. Questions about rights of the voters to initiate draft laws have been repeatedly discussed also in the Constitutional Court and the Supreme Court, especially analysing content of the precondition put forth for voters' legislative initiatives that the draft law must be "fully elaborated" and regarding scope of powers of the CEC during the registration process.

\section{A concept of fully elaborated draft law}

According to Article 78 of the Constitution, the voters are entitled to initiate both draft amendments to the Constitution and draft laws. Besides, the procedure of submission and criteria to be met do not differ for draft amendments to the Constitution and draft laws, therefore, for the purpose of this article a term draft law will imply also draft amendments to the Constitution. The voters can initiate amendments to any existing law and completely new law.

According to Article 23(3) of the Law, the first steps of implementation of voters' legislative initiative begin at the moment when the initiative group submits to CEC a submission of the draft law or draft amendments to the Constitution, in support of which the collection of signatures is planned. The initiative group must prepare a draft law or draft amendments to the Constitution fully elaborated in terms

Law “On National Referendum, Legislative Initiative and European Citizens' Initiative”. Available at: https://likumi.lv/ta/en/en/id/58065-on-national-referendum-legislative-initiative-and-europeancitizens-initiative [last viewed October 25, 2019].

2 Transcript of the $20^{\text {th }}$ sitting of the IV Session of the Constitutional Assembly 09.11.1921. Available at: Latvijas Satversmes Sapulces stenogrammu izvilkums (1920-1922). Rigga: Tiesu namu agentūra, 2006, p. 467.

3 See Article 23 of the Law. 
of form and content, in support of which collection of signatures is planned. Once an initiative group has lodged a submission on draft law or draft amendments to the Constitution to CEC, it must examine the submitted documentation and adopt one of three decisions within 45 days: 1 ) to register the draft law; 2) to set a term for correcting any faults in the submission and the draft law or draft amendment to the Constitution (for example, in cases, when the title of the law must be specified, the text of the draft law must be corrected in accordance with requirements of the Latvian literary language and orthography, or terminology used in the draft law must be specified); (3) to reject registration of the draft law. ${ }^{4}$

If the draft law submitted by the initiative group is registered, the CEC announces 12 months of collection of signatures on certain draft law. If the support mentioned in Article 78 of the Constitution is achieved during the period in question, i.e. it has been signed by $1 / 10$ of Latvian electorate, the draft law is submitted to the State President according to Article 78 of the Constitution and he submits it for consideration in the Saeima.

According to Article 23(5) of the Law, The Central Election Commission shall refuse registration of the draft law or draft amendments to the Constitution only in 2 cases: firstly, if the initiative group does not conform to the requirements of the Law (preconditions put forth to initiative groups was described above), or, secondly, if the draft law or draft amendments to the Constitution is not fully elaborated in terms of form or content (emphasis by the author).

When deciding on registration of the draft law submitted by the initiative group, CEC may request information, explanations and opinions from public and municipal authorities necessary for deciding on this issue, as well as to invite experts. Rights implied in this law are exercised in practice, for example, when asking teaching staff of law faculties of Latvian universities to provide opinions about a certain draft.

In actual life, initiative groups have often faced problems with meeting the criterion of fully elaborated draft law, and therefore CEC has rejected registration of the submitted draft laws. Information in possession of CEC reveals that from 2012 until now 12 initiatives have been registered ${ }^{5}$, whereas registration of 9 draft laws or draft amendments to the Constitution were rejected ${ }^{6}$.

The Law states that a decision on rejecting registration of draft law or draft amendments to the Constitution adopted by CEC can be appealed in the Administrative Case Department of the Supreme Court. Several initiators have exercised this right and consequently it has led to the case law in Latvia giving certain criteria that a draft law should fulfil to qualify as fully elaborated.

See Article 23(4) of the Law.

See Initiatives registered for collection of signatures are available at: https://www.cvk.lv/lv/ iniciativas/veletaju-iniciativas/registretas-iniciativas and https://www.cvk.lv/lv/iniciativas/veletajuiniciativas/iniciativas-par-kuram-parakstu-vaksana-noslegusies [last viewed October 28, 2019].

6 Initiatives with rejected registration available at: https://www.cvk.lv/lv/iniciativas/veletajuiniciativas/iniciativas-kuram-registracija-atteikta. [last viewed October 28, 2019]. 


\subsection{Scope of concept "fully elaborated draft law in terms of form"}

A criterion that a draft law must be fully elaborated in terms of form requires compliance with conditions of legal technique. Requirements for the form of the draft law are primarily found in the Cabinet Regulation "Regulation on elaboration of draft regulatory enactments" 7 , as well as different guides to elaboration of regulatory enactments. ${ }^{8}$ Authoritative legal scientist from the 1920s, Prof. Kārlis Dišlers, at his time pointed out that in order to deem a draft law to be fully elaborated in terms of form, the draft law must clearly show "what existing laws or articles of laws are cancelled or amended, and logically comprehensible content of amendments and possible new articles". A draft law must contain legal provisions - it cannot be formulated as a declarative statement or a conceptual proposal. ${ }^{10}$

The Supreme Court in its judgement of year 2014 has pointed out that according to provisions of the Rules of Procedure of the Saeima also draft law or draft amendments to the Constitution submitted by the totality of citizens must be executed as draft law. At the same time, it must be taken into account that formal requirements must be constructed in a way to exclude drafts that are not suitable due to formal shortcomings (for example, draft is not executed as draft law, draft has unclear content, text has logic mistakes etc.). ${ }^{11}$

The draft law must also contain transitional provisions or provisions on effectiveness of the law, if required so by the nature of amendments. ${ }^{12}$ As shown by the practice of CEC, meeting of formal criterion usually has not been a difficulty for the initiative groups, but initiative registrations were mainly rejected due to shortcomings in the draft law's content, making it not fully elaborated.

\subsection{Scope of concept "fully elaborated draft law in terms of content"}

Any law must comply with the legal system in terms of content. It means that by using law application methodology and especially interpretation methodology,

The Cabinet Regulation of 03.02.2009 No. 108. Regulation on Drafting Regulatory Enactments. Latvijas Vēstnesis, 17.02.2009. No. 26 (4012).

8 Normatīvo aktu projektu izstrādes rokasgrāmata. [Handbook for Drafting Regulatory Enactments] Riga: Valsts kanceleja. 2016. Available at: https://tai.mk.gov.lv/book/1/chapter/23 [last viewed September 25, 2019].

9 Dišlers K. Vai Centrālajai vēlēšanu komisijai ir tiesība pārbaudìt iesniegtos likumprojektus [Does the Central Election Commission Have the Right to Verify the Submitted Draft Laws]. Jurists, No. 5, 135., 136. sl., 1928.

10 Letter by the Department of Constitutional and Administrative Law of the Faculty of Law, University of Latvia to CEC No. 2020-V10-36. Jurista Värds, No. 40 (739), 02.10.2012, p. 21.

11 Judgement of the Supreme Court of 28 March 2014 in case No. SA-3/2014, para. 9. Available at: www.at.gov.lv [last viewed October 12, 2019].

12 Pastars E. Referendumu nedienas. Diena. 03.08.2002. Quoted from: Saeimas Juridiskā biroja vēstule No. 12/13-3-n/36-11/12 Centrālajai vēelěšnu komisijai. Jurista Värds, No. 40 (739), 02.10.2012, p. 18. 
the law must be suitable and must not contradict legal provisions that are superior or have a higher priority in power hierarchy. ${ }^{13}$

During recent years, the case law in Latvia has become constant regarding the content of a draft law to qualify as fully elaborated ${ }^{14}$. As the Constitutional Court stated in its decision of 19 December 2012 on termination of proceedings in the so-called language referendum case ${ }^{15}$, a draft law cannot be deemed to be fully elaborated in terms of content, if: 1) it intends to decide issues beyond the scope of the law; 2) in case of acceptance it would contradict provisions, principles and values implied in the Constitution; 3) in case of acceptance it would contradict international liabilities of Latvia. The Supreme Court also constantly complies with these evaluation criteria for a "fully elaborated" draft law, when examining cases on appeal of CEC decisions, referring to said decision of the Constitutional Court. The Venice Commission of the Council of Europe has also pointed out that a draft law submitted for a referendum must comply with the legal provisions of the supreme law authority, international law and principles of the European Parliament (democracy, human rights and law governed state). ${ }^{16}$

In its practice, CEC has repeatedly rejected registration of draft laws that contradicted the Constitution or international contracts binding to Latvia. For example, registration of a draft law envisaging to introduce individual material liability of the Saeima deputies, ministers and state secretaries, i.e. stating that these officials are "individually materially liable for loss resulting from decisions taken, signed or endorsed by such officials" was rejected and collection of signatures was not started on the basis of contradiction to the Constitution. ${ }^{17}$ In this particular situation, it was concluded that this draft law would contradict the principle of unaccountability of the Saeima deputies stipulated in Article 28 of the Constitution, namely, "Members of the Saeima may not be called to account by any judicial, administrative or disciplinary process in connection with their voting or their views as expressed during the execution of their duties. [..]" The said draft law was interesting also because it envisaged holding these officials liable, however, the next article stated that "Procedure of imposing the material liability shall be elaborated

13 Judgement of the Supreme Court of 28 March 2014 in case No. SA-3/2014, para. 10, see also Letter No. 12/13/-3-n/36-11/12 of the Saeima Legal Office to the Central Election Commission. Jurista Värds, No. 40 (739), 02.10.2012, p. 18.

14 Judgement of the Supreme Court of 18 December 2013 in case No. 2013-06-01 and judgement of 28 March 2014 in case No. SA-3/2014. Available at: www.at.gov.lv [last viewed September 25, 2019].

15 Decision of the Constitutional Court of 19 December 2012 in case No. 2012-03-01 on termination of proceedings. Available at: https://likumi.lv/doc.php?id=253569 [last viewed September 25, 2019].

16 Code of Good Practice on Referendums, CDL-AD(2007)008rev, Venice, 16-17 March 2007, point III.3. Available at: http://www.venice.coe.int/webforms/documents/?pdf=CDLAD $\% 282007 \%$ 29008-e [last viewed September 25, 2019].

17 Decision by CEC of 19.05.2015 No. 4 and Decision of 02.04.2015. No. 3 "On the Draft Law Submitted by the Association "Atvērtās pārvaldības partnerība Latvijā" On the Personal Liability of Members of the Saeima, Ministers and Secretaries of the State". Available at: https://www.cvk.lv/ pub/public/31136.html; https://www.cvk.lv/pub/public/31107.html; https://www.cvk.lv/pub/ public/31134.html [last viewed September 25, 2019]. 
by the Cabinet of Ministers in a separate draft law to be submitted to the Saeima within six months". Regarding a version of this article, CEC referred to conclusions of the Constitutional Court and pointed out that such article would contradict the principle of legal certainty. The following requirement arises from the principle of legal certainty: "a legal provision defining restrictions of fundamental rights of a person must be clear and as accurate as possible.[... Issuer of the legal provision must take care of formulation of the legal provision to make it as unambiguous as to allow correct interpretation and application, while a person could be aware of the legal consequences of its application". ${ }^{18}$ Namely, this article of the draft law is actually a thesis or a goal, but it does not define a mechanism for achieving it; therefore, the draft law was considered as declarative and unclear, because if the voters signed the draft law they would not have any clarity about its legal consequences and what would be the practical mechanism of imposition of material liability.

Similarly, registration of a draft law intending to define a new case for referendum at the level of law (instead of Constitution) was rejected and no collection of signatures was started. Noteworthy, proposals promoted by various initiative groups have been submitted to CEC with a shared idea - at the time when lats was the national currency of Latvia - these initiative groups wanted to introduce a new case for referendum at the level of law, i.e., to prescribe that official currency change can be decided only in referendum. One of the initiatives that was submitted in January 2013, envisaged amendments to the Law On the Bank of Latvia, defining lats as the sole means of payment in Latvia - until the referendum decides otherwise. ${ }^{19}$ Some initiatives tried to determine referendum arrangement formalities in a new law "On participation of nation in change of legal means of payment in the Republic of Latvia" ${ }^{20}$. In all these cases, CEC turned down registration of these draft laws, providing a reasonable conclusion that introduction of a new case for referendum is an issue of amendments to the Constitution for which the Saeima or totality of citizens of Latvia must decide as a constitutional legislator. CEC referred to Article 64 of the Constitution ${ }^{21}$ and pointed out: "Since the Constitution clearly lays down the cases of participation of the totality of citizens as public authority,

18 See, for example, Judgement of the Constitutional Court of 28 June 2013 in case No. 2012-26-03, para. 14. Available at: http://www.satv.tiesa.gov.lv/web/viewer.html?file=/wp-content/uploads/ 2012/12/2012-26-03_Spriedums_ENG.pdf\#search=2012-26-03 [last viewed September 11, 2019].

19 Decision by CEC of 18.03.2013 No. 14 On draft law "Amendments to the Law On the Bank of Latvia" submitted by the initiative group. Available at: https://www.cvk.lv/pub/upload_file/14_ pilnais.pdf [last viewed September 11, 2019].

20 Decision by CEC of 31.01.2013. No. 5 On draft law "On nation's participation in decision making concerning a term of introduction of euro currency" submitted by the initiative group. Available at: https://www.cvk.lv/pub/upload_file/PV\%202013/31012013_CVK_lemums_Nr_5_izversts. pdf [last viewed September 11, 2019]; Decision No. 35 of 18.09.2013 On draft law “'On nation's participation in change of legal means of payment in the Republic of Latvia" submitted by association "Latviešu Biedrïba”. Available at: https://www.cvk.lv/pub/upload_file/35_pilnais.pdf [last viewed September 11, 2019]. See p. 11.

21 Article 64 of the Constitution stipulates: "The Saeima, and also the people, have the right to legislate, in accordance with the procedures, and to the extent, provided for by this Constitution." Namely, it follows from this article that rights of the people as the legislator are restricted and their scope is defined by the Constitution. 
the law or other regulatory enactment cannot include other cases for referendum. A new referendum case, not previously defined in the Constitution, can be introduced only via amending the Constitution, and the Saeima or the totality of citizens of Latvia as constitutional legislator must collectively decide on that".22 It must be mentioned that in the decision of CEC discussed above, an emphasis was placed on several aspects that show further potential contradictions also with the international liabilities assumed by Latvia.

It has been admitted in the case law that a fully elaborated draft law in terms of content is a draft law that does not contradict the international liabilities assumed by the state. Initiative that aimed at amending Article 4 of the Constitution by supplementing it with a sentence "National currency of Latvia is lats" lodged by the voters was turned down by CEC in 2013 as non-compliant with international liabilities of the state. ${ }^{23} \mathrm{CEC}$ concluded that an issue on means of payment in Latvia is related to accession of Latvia to the European Union and participation in the Economic and Monetary Union. Article 119 of Treaty on the Functioning of the European Union list actions to be taken by the European Union and its Member States within the framework of Economic and Monetary Union. One of activities to be taken by the member state is also an introduction of a single currency. It means that a question about means of payment in Latvia (keeping lats or introducing euro) applies to conditions of being a part of the European Union and introduction of euro is a liability undertaken with the international treaty. ${ }^{24}$ When examining the case where the said decision of CEC was contested, the Supreme Court in its judgement of year 2014 stated: "Term 'fully elaborated' found in Article 78 of the Constitution must be understood as implying also a legislative initiative of such totality of citizens that respects international liabilities of Latvia in a way that it provides measures of preventing contradictions with international liabilities of Latvia before entering in force of the law or amendments to the Constitution under the initiative or concurrently with it. The draft law that would oppose the international liabilities of Latvia in case of acceptance is not to be considered as 'fully elaborated"'.25

Any draft law or draft amendments to the Constitution submitted must also have appropriate quality - it may not have internal contradictions of other ambiguities. Besides, the entire text of a draft law must meet the criterion "fully elaborated", and even if the draft law does not qualify as fully elaborated in some part, that shortcoming cannot be prevented and it must be admitted that the draft law generally does not satisfy the requirements of Article 78 of the Constitution and that shortcoming cannot be eliminated, for example, by excluding the unsuitable

22 Available at: https://www.cvk.lv/pub/upload_file/14_pilnais.pdf [last viewed September 11, 2019], paras 15, 16.

23 Decision by CEC of 14.05.2013. No. 17. On the draft law "Amendment to the Constitution of the Republic of Latvia" submitted by the association "Par latu, pret eiro". Available at: https://www. cvk.lv/pub/upload_file/17_pilnais.pdf [last viewed September 11, 2019].

24 Ibid.

25 Judgement of the Supreme Court of the Republic of Latvia of 28 March 2014 in case No. SA-3/2014. Available at: www.at.gov.lv [last viewed September 12, 2019]. 
part from text of the draft law. ${ }^{26}$ The draft law must be fully elaborated at the moment of submission to CEC, and the submitter cannot claim that it could be improved after registration or that improvements could be left to the Saeima. ${ }^{27}$

A precondition that the draft law must be fully elaborated is especially important, because in compliance with Article 78 of the Constitution, if Saeima failed to support the submitted draft law or adopted it with amendments in content, this incomplete draft law would be presented for referendum and could end with potential acceptance of "spoilage". Notwithstanding the fact that text of a draft law submitted by the initiative group cannot be amended after its registration, one must ensure that a draft that contradicts the basic values of democratic and legal state would not be presented for referendum. According to Article 78 of the Constitution, the same version of the draft law must be presented for referendum that was initiated by $1 / 10$ of electorate, and as the Constitutional Court has concluded: "[..] if poor quality or anti-constitutional draft laws were presented for referendum on a regular basis, the very idea of legislative initiative of voters would be levelled out and over the course of time the civic activity of voters could decrease". ${ }^{28}$

\section{Restrictions of content of voters' initiatives}

The understanding that voters' initiatives cannot pertain to issues that fall within the competence of other bodies of state power has been consolidated in legal science, for example, if the Constitution states that amnesty in Latvia is given by the Saeima, the voters could not initiate a draft law on amnesty just like the voters could not adopt the Rules of Procedure of the Saeima (because, according to Article 21 of the Constitution, it is an exclusive prerogative of the Saeima) etc. Professor K. Dišlers in his time specified that a totality of citizens may initiate adoption of only abstract and general legal norms, but not administrative or jurisdictive acts. ${ }^{29}$

Pre-war legal science already discussed topics whether the voters were entitled to initiate issues on cases mentioned in Article 73 of the Constitution, like the cases that cannot be passed to referendum (i.e. budget and laws on borrowings, taxes, customs, railway tariffs, military service, declaration and starting of war, conclude peace, announcement of extraordinary situation and its termination, mobilisation and demobilisation as well as contracts with other foreign countries). For example,

26 See Decision by CEC of 19.05.2015 No.4, para. 8; Letter by the Saeima Legal Bureau No. 12/133-n/36-11/12 to the Central Election Commission. Jurista Värds, No. 40 (739), 02.10.2012, p. 17.

27 Article 12 of Decision No. 4 of 19.05 .2015 by CEC; see also Article 17 of Decision No. 13 of 02.04.2015 by CEC.

28 Judgement of the Constitutional Court of the Republic of Latvia of 18 December 2013 in case No. 2013-06-01, para. 13.2. Available at: http://www.satv.tiesa.gov.lv/wp-content/ uploads/2016/02/2013-06-01_Spriedums.pdf [last viewed August 28, 2019].

29 Dišlers K. Nekonstitucionāls ierosinājums [An Unconstitutional Proposal]. Jaunākās Ziņas, 17.06.1927. Quoted from: Saeimas Juridiskā biroja vēstule, No.12/13-3-n/36-11/12 Centrālajai vēlēšanu komisijai [Letter by the Saeima Legal Bureau No. 12/13-3-n/36-11/12 to the Central Election Commission]. Jurista Värds, No. 40 (739), 02.10.2012, p. 18. 
professor K. Dišlers in his work published in the 1930s pointed out that the restrictions mentioned in Article 73 of the Constitution pertain only to referendums but not to initiation of laws. At the same time, the professor indicated that it would be hard to imagine an actual life situation, where the voters submitted proposals regarding budget or contracts with foreign countries, but if voters would like to initiate a draft law, for example, on introduction of some new tax or cancellation of an existing one, K. Dišlers believed that people could not be denied of such right. ${ }^{30}$ The professor specified that in these cases a draft law submitted by the voters could become a law only if the Saeima adopted it. Namely, in K. Dišlers' opinion, consequences mentioned in the second sentence of Article 78 of the Constitution if the Saeima did not accept the draft law lodged by the voters without amendments in terms of content, it could not be passed for referendum - would not be applicable to such cases.

The said issue has brought about polemics in contemporary law science. For example, Dr. iur. I. Nikul,ceva has also stated in her doctoral thesis that she supports the aforementioned conclusions of professor K. Dišlers ${ }^{31}$, and she believes these restrictions in case of doubt should be interpreted more narrowly. Meanwhile, the experts of constitutional law J. Pleps and E. Pastars have pointed out that the restrictions listed in Article 73 of the Constitution should also be applicable to voters' initiatives. ${ }^{32}$ In the judgement of 2014 the Constitutional Court, in examining a case, in which the primary issue to be reviewed did not pertain directly to restrictions upon voters' initiative, noted, inter alia, that "voters' rights to legislative initiative are not applicable to draft laws, which, pursuant to Article 73 of the Satversme, cannot be submitted for a national referendum"33. It must be added, that currently, in 2019, a draft law "Amendment to the Law On Real Estate Tax" submitted by an initiative group has been registered by CEC for collection of signatures, and it envisages amendments to the law that a natural person's only housing is not subject to real estate tax if the property meets the criteria listed in the draft law. ${ }^{34}$

To consider draft amendments to the Constitution as fully elaborated, their content must not contradict those provisions of the Constitution that the draft amendments do not offer to amend: either the core of the Constitution or the basic provision laid down in proclamation act of the State of Latvia that Latvia

30 Dišlers K. Ievads Latvijas valststiesību zinātnē [Introduction to the Science of Latvian State Law]. Rìga: A. Gulbis, 1930, p. 117.

31 Nikuḷceva I. Tautas nobalsošana un vēlētāju likumdošanas iniciatīva. Promocijas darbs [National Referendum and Voters' Legislative Initiative. Thesis]. Rìga: Latvijas Universitāte, 2012, pp. 94-95.

32 Pleps J., Pastars E. Vai tauta var Saeimā iesniegt budžeta projektu [May the People Submit to the Saeima a Draft Budget]. Jurista Vārds, No.18 (251), 10.09.2002 and No. 19(252), 24.09.2002.

33 Judgement of the Constitutional Court of the Republic of Latvia of 12 February 2014 in case No. 2013-05-01, para. 14.4. Available at: http://www.satv.tiesa.gov.lv/wp-content/ uploads/2016/02/2013-05-01_Spriedums.pdf [last viewed September 19, 2019].

34 Available at: https://www.cvk.lv/uploads/files/Iniciativas/NIN_likumprojekta\%20teksts.pdf [last viewed September 19, 2019]. 
is independent and democratic republic. ${ }^{35}$ At the end of 2011, when, according to regulation of that time, a draft amendment to the Constitution signed by $1 / 10$ of electorate and envisaging to strengthen status of the Russian language as the second official language ${ }^{36}$ was submitted to the Saeima, public and layers' community lit up with discussions on whether the voters can initiate any kind of amendments to the Constitution. In 2012, the Constitutional Law Commission set up under auspices of the State President's office, published its opinion "On constitutional foundations of the State of Latvia and the inviolable core of the Constitution", which included the conclusion that voters did not have an unrestricted right to initiate any constitutional amendments. Respectively, the Commission pointed out that the Constitution holds values that cannot be amended, and one of such is also the official state language, given that Latvia is a national State and the Latvian language means the identity of this State. ${ }^{37}$ Also, the decision of December 2012 by the Constitutional Court on termination of proceedings in case No. 2012-03-01 has brought forward the notion of values enshrined in the Constitution, obliging every legislation's subject to stick to the principle - to act not only according to provisions and principles of the Constitution, but also in keeping with the values, pointing out that "not only a legislator implementing legislation rights independently the Saeima - but also a legislator exercising legislation rights in certain cases the nation - must comply with provisions of legal power and respect constitutional values embedded therein." ${ }^{3}$ As pointed out by the Constitutional Court Judge G. Kusinšs, referendum can amend the Constitution, if such amendment does not exclude any element of Constitutional core or does not contradict any element of Constitutional core. "It is possible to add to the core of the Satversme through a national referendum; however, a totally different core of the Satversme may be established only by adopting a new Satversme". ${ }^{9}$

CEC's right to assess whether the draft law has been fully elaborated clearly follows from regulation of the current law; however, CEC is not entitled to evaluate usefulness of the draft law or to evaluate its acceptability or perform political

35 78. pants. Latvijas Republikas Satversmes komentāri. [Article 78. The Commentaries of the Constitution of the Republic of Latvia]. V nodaļa. Likumdošana. Autoru kolektīvs prof. R. Baloža zinātniskā redakcijā, Rīga: Latvijas Vēstnesis, 2019, p. 286.

36 Bērziņš iesniedz Saeimā likumprojektu par divvalodību [Bērziņš Submits to the Saeima a Draft Law on Two Official Languages]. Leta. 20.12.2011. Available at: http://www.tvnet.lv/zinas/ latvija/404238-berzins_iesniedz_saeima_likumprojektu_par_divvalodibu [last viewed September 19, 2019].

37 Latvijas valsts kodolu meklejot [Searching for the Core of the State of Latvia]. Jurista Vârds, No. 6 (705), 07.02.2012; Opinion by the Commission of Constitutional Law from 17.09.2012 on the Constitutional Foundations of the State of Latvia and Inviolable Core of the Satversme. Available at: http://www.president.lv/images/modules/items/PDF/17092012_Viedoklis_2.pdf [last viewed August 17, 2019].

38 Decision of the Constitutional Court of the Republic of Latvia of 19 December 2012 on Terminating Legal Proceedings in case No. 2012-03-01. Latvijas Vēstnesis, No. 200 (4803), 20.12.2012, para. 18.3.

39 Platace L. Vēlētāju tiesības ierosināt referendumus pārmainu priekšā [Voters' Right to Initiate Referendums in the Wake of Changes]. 25.07.2012. Available at: http://m.lvportals.lv/visi/likumiprakse $? \mathrm{id}=250193$ ? show $=$ coment [last viewed August 17, 2019]. 
assessment that can be done solely by the legislator - the Saeima or the people. ${ }^{40}$ CEC must perform only legal assessment of the draft law. As pointed out by the Constitutional Court, CEC must register every draft law submitted by the voters, except where it obviously (emphasized by author) has not been fully elaborated in terms of content. ${ }^{41}$ If CEC establishes that a draft law is not fully elaborated, it adopts a decision on refusing to register the draft law. As the Supreme Court has found, the decision by which CEC refuses registration and transfer of a draft law submitted by voters for collection of signatures is not to be recognised as being an administrative act, because it is adopted within the framework of legislative procedure. ${ }^{42}$

Article $23^{1}$ of the Law states that the initiative group can appeal the decision to reject registration of a draft law or draft amendments to the Constitution adopted by the CEC to the Department of Administrative Cases of the Supreme Court, where it examines the case as the court of first instance, and it means that the case is examined as to its merits. ${ }^{43}$ Thus, in proceedings the Supreme Court must evaluate whether the draft law submitted by the voters is fully elaborated. ${ }^{44}$

In practice, CEC decisions to reject registration of draft laws have been appealed several times, including requests to the Supreme Court to oblige CEC to approve legislative proposals for collection of signatures, and the court has also been requested to enforce moral compensation. ${ }^{45}$ Interestingly, the Supreme Court has exercised rights arising out of the Law On Constitutional Court ${ }^{46}$ and addressed the Constitutional Court with an application requesting to evaluate compliance of Article 23(5)(2) and Article 23 ${ }^{1}(1)$ of the Law with Article 1 of the Constitution. The Supreme Court was concerned if the legal provision qualifying CEC to evaluate voters' initiatives in terms of content and qualifying the Supreme Court to examine complaints about such decisions does not contradict the principle of separation of powers. ${ }^{47}$ The Constitutional Court in its judgement passed in 2013 concluded that there was no contradiction between the contested law and

40 Judgement of the Constitutional Court of the Republic of Latvia of 18 December 2013 in case No. 2013-06-01, para. 14.3. Available at: http://www.satv.tiesa.gov.lv/wp-content/ uploads/2016/02/2013-06-01_Spriedums.pdf [last viewed November 2, 2019].

${ }^{41}$ Ibid., paras 14.3 and 15.4

42 Decision of the Senate of the Supreme Court of the Republic of Latvia of 20 February 2013 in case No. A420577912 SA-1/2013, para. 9.

43 Administrative Procedure Law. Article 105(1). Available at: https://likumi.lv/ta/en/en/id/55567administrative-procedure-law [last viewed November 2, 2019].

44 Judgement of the Constitutional Court of the Republic of Latvia of 18 December 2013 in case No. 2013-06-01. Available at: http://www.satv.tiesa.gov.lv/wp-content/ uploads/2016/02/2013-06-01_Spriedums.pdf, Article 15.4 [last viewed November 2, 2019].

45 Decision by the Supreme Court of the Republic of Latvia of 11 February 2013 in case No. A420577912 SA- 1/2013. Available at: at.gov.lv/files/files/1-sa-2013.doc [last viewed November 02, 2019].

46 The Constitutional Court Law. Available at: https://likumi.lv/ta/en/en/id/63354-constitutionalcourt-law [last viewed November 2, 2019].

47 See Decision of the Senate of the Supreme Court of the Republic of Latvia of 20 February 2013 in case No. A420577912 SA-1/2013, para. 9. Available at: at.gov.lv/files/files/ [last viewed November 2, 2019]. With this decision the Supreme Court decided to amend the content of its decision of 11.02.2013 on submission of the application to the Constitutional Court. 
Constitution - the Supreme Court must find out whether the draft law submitted by the voters was really and obviously fully elaborated in terms of content and whether CEC in its decision had legally justified non-compliance of the draft law with the relevant legal provision. ${ }^{48}$ The Constitutional Court also pointed out that it had an exclusive competence to admit legal provisions to be non-compliant with the legal provisions of the supreme legal powers and declare them invalid, however, also the administrative court, within the framework of each case, had to make sure that the applicable legal provision complied with legal provisions of the supreme legal powers. Thus, the Constitutional Court decided that this regulation conformed to Article 1 of the Constitution. ${ }^{49}$

\section{Conclusions}

1. The term fully elaborated draft law or amendments to the Constitution used in Article 78 of the Constitution includes criteria of both form and content of the draft law. In practice, the initiative groups often had problems to fulfil a criterion of fully elaborated draft law and, therefore, CEC had refused their registration for further collection of signatures.

2. A criterion that a draft law must be fully elaborated in terms of form requires compliance with conditions of legal technique. Proper form of a draft law is defined in the Cabinet Regulation No. 108 "Regulation on executing of draft legislative acts". Additionally, the draft law or draft amendments to the Constitution submitted by the totality of citizens must be executed as draft law, i.e., it must contain legal provisions and it cannot be executed as declarative statement or conceptual proposal.

3. Regarding evaluation of the form of a draft law, one must take into consideration a conclusion from the case law that formal requirements must be strict enough to exclude drafts that cannot be applied due to formal shortcomings. Introducing criteria that are too hard to attain could make this right of totality of citizens an especially hard-to-implement procedure.

4. As shown by the practice, i.e. decisions of CEC, meeting of formal criterion usually has not been a difficulty for the initiative groups, but initiative registration was mainly rejected, because the draft laws had not been fully elaborated in terms of content.

5. Case law in Latvia has established certain features that a draft law must have to be identified as fully elaborated in terms of content. The draft law cannot be

48 Judgement of the Constitutional Court of the Republic of Latvia of 18 December 2013 in case No. 2013-06-01, paras 15.3 and 15.4. Available at: http://www.satv.tiesa.gov.lv/wp-content/ uploads/2016/02/2013-06-01_Spriedums.pdf [last viewed November 2, 2019].

49 Ibid., para. 15.1. 
considered as fully elaborated in terms of content, if: 1) it intends to decide issues beyond the scope of the law; 2) in case of acceptance it would contradict provisions, principles and values implied in the Constitution; 3) in case of acceptance it would contradict international liabilities of Latvia.

6. In particular, to consider draft amendments to the Constitution to be fully elaborated, their content must not contradict either those provisions of the Constitution that the draft amendments do not offer to amend, or the core of the Constitution.

7. A draft law must be fully elaborated at the moment of submission to CEC, and the submitter cannot use a pretence that it could be improved after registration or that improvements could be left to the discretion of the Parliament.

8. The condition that the draft law must be fully elaborated is especially important, because in compliance with Article 78 of the Constitution, if 1/10 of the electorate failed to support the submitted draft law or adopted it with amendments, this incomplete draft law would be presented for referendum and ended with potential acceptance of "spoilage". Notwithstanding the fact that text of the draft law submitted by the initiative group cannot be amended after its registration, it must be ensured that the draft law or amendment to the Constitution contradicting the basic values of democratic and legal state would not be presented for referendum.

\section{BIBLIOGRAPHY}

\section{Literature}

1. 78. pants. Latvijas Republikas Satversmes komentāri [Article 78. The Commentaries of the Constitution of the Republic of Latvia]. V nodaļa. Likumdošana. Autoru kolektivvs prof. R. Baloža zinātniskā redakcijā, Rīga: Latvijas Vēstnesis, 2019, p. 286.

2. Bērziņš iesniedz Saeimā likumprojektu par divvalodību [Bērziņš Submits to the Saeima a Draft Law on Two Official Languages]. Leta. 20.12.2011. Available at: http://www.tvnet.lv/ zinas/latvija/404238-berzins_iesniedz_saeima_likumprojektu_par_divvalodibu [last viewed September 19, 2019].

3. Dišlers K. Ievads Latvijas valststiesību zinātnē [Introduction to the Science of Latvian State Law]. Rìga: A. Gulbis, 1930, p. 117.

4. Dišlers K. Nekonstitucionāls ierosinājums [An Unconstitutional Proposal]. Jaunākās Ziņas, 17.06.1927. Quoted from: Saeimas Juridiskā biroja vēstule Nr.12/13-3-n/36-11/12 Centrālajai vēlēšanu komisijai [Letter by the Saeima Legal Bureau No. 12/13-3-n/36-11/12 to the Central Election Commission]. Jurista Vârds, No. 40 (739), 02.10.2012, p. 18.

5. Dišlers K. Vai Centrālajai vēlēšanu komisijai ir tiesība pārbaudìt iesniegtos likumprojektus [Does the Central Election Commission Have the Right to Verify the Submitted Draft Laws]. Jurists, No. 5, 1928, 135., 136. sl.

6. Latvijas valsts kodolu meklējot [Searching for the Core of the State of Latvia]. Jurista Värds. No. 6 (705), 07.02.2012.

7. Nikuḷceva I. Tautas nobalsošana un vēlētāju likumdošanas iniciatīva. Promocijas darbs [National Referendum and Voters' Legislative Initiative. Thesis]. Riga: Latvijas Universitāte, 2012, pp. 94-95. 
8. Normatīvo aktu projektu izstrādes rokasgrāmata [Handbook for Drafting Regulatory Enactments]. Riga: Valsts kanceleja, 2016. Available at: https://tai.mk.gov.lv/book/1/ chapter/23 [last viewed September 25, 2019].

9. Opinion by the Commission of Constitutional Law from 17.09.2012 on the Constitutional Foundations of the State of Latvia and Inviolable Core of the Satversme. Available at: http:// www.president.lv/images/modules/items/PDF/17092012_Viedoklis_2.pdf $\quad[$ last viewed August 17, 2019].

10. Pastars E. Referendumu nedienas. Diena. 03.08.2002. Quoted from: Saeimas Juridiskā biroja vēstule No. 12/13-3-n/36-11/12 Centrālajai vēlēšanu komisijai. Jurista Vārds, No. 40 (739), 02.10.2012, p. 18 .

11. Platace L. Vēlētāju tiesības ierosināt referendumus pārmaiṇu priekšā [Voters' Right to Initiate Referendums in the Wake of Changes]. 25.07.2012. Available at: http://m.lvportals.lv/visi/ likumi-prakse?id=250193 ?show=coment [last viewed August 17, 2019].

12. Pleps J., Pastars E. Vai tauta var Saeimā iesniegt budžeta projektu [May the People Submit to the Saeima a Draft Budget]. Jurista Vārds, No. 18 (251), 10.09.2002 and No. 19 (252), 24.09.2002.

\section{Legislative acts}

1. The Constitution of the Republic of Latvia. Available at: https://likumi.lv/ta/en/id/57980the-constitution-of-the-republic-of-latvia [last viewed October 2, 2019].

2. Law "On National Referendum, Legislative Initiative and European Citizens' Initiative". Available at: https://likumi.lv/ta/en/en/id/58065-on-national-referendum-legislativeinitiative-and-european-citizens-initiative [last viewed October 25, 2019].

3. The Constitutional Court Law. Available at: https://likumi.lv/ta/en/en/id/63354constitutional-court-law [last viewed November 2, 2019].

4. Administrative Procedure Law. Available at: https://likumi.lv/ta/en/en/id/55567administrative-procedure-law [last viewed November 2, 2019].

5. The Cabinet Regulation of 03.02.2009 No. 108. Regulation on Drafting Regulatory Enactments. Latvijas Vēstnesis, No. 26 (4012), 17.02.2009.

\section{Legal practice}

1. Judgement of the Constitutional Court of the Republic of Latvia of 12 February 2014 in case No. 2013-05-01. Available at: http://www.satv.tiesa.gov.lv/web/viewer.html?file=/wpcontent/uploads/2016/02/2013-05-01_Spriedums.pdf\#search= [last viewed November 2, 2019].

2. Judgement of the Constitutional court of the Republic of Latvia of 18 December 2013 in case No. 2013-06-01. Available at: http://www.satv.tiesa.gov.lv/wp-content/ uploads/2016/02/2013-06-01_Spriedums.pdf [last viewed November 2, 2019].

3. Judgement of the Constitutional Court of the Republic of Latvia of 28 June 2013 in case No. 2012-26-03. Available at: http://www.satv.tiesa.gov.lv/web/viewer.html?file=/ wp-content/uploads/2012/12/2012-26-03_Spriedums_ENG.pdf\#search=2012-26-03 [last viewed September 11, 2019].

4. Decision of the Constitutional Court of the Republic of Latvia of 19 December 2012 on Terminating Legal Proceedings in Case No. 2012-03-01. Latvijas Vēstnesis, No. 200 (4803), 20.12.2012. 
5. Judgement of the Supreme Court of the Republic of Latvia of 28 March 2014 in case No. SA3/2014. Available at: www.at.gov.lv [last viewed October 12, 2019].

6. Decision of the Senate of the Supreme Court of the Republic of Latvia of 20 February 2013 in case No. A420577912 SA-1/2013. Available at: www.at.gov.lv [last viewed October 12, 2019].

7. Decision by CEC of 19.05.2015, No. 4 and Decision by CEC of 02.04.2015, No. 3 "On the Draft Law Submitted by the Association "Atvērtās pārvaldības partnerība Latvijā" "On the Personal Liability of Members of the Saeima, Ministers and Secretaries of the State. Available at: https://www.cvk.lv/pub/public/31136.html; https://www.cvk.lv/pub/ public/31107.html; https://www.cvk.lv/pub/public/31134.html [last viewed September 25, 2019].

8. Decision by CEC of 07.11.2013, No. 37 "On the Draft Law Submitted by the Association "Sargāsim mūsu bērnus!" "Amendments to "Protection of the Rights of the Child Law"”. Available at: https://www.cvk.lv/pub/public/30672.html [last viewed September 25, 2019].

9. Decision by CEC of 18.09 .2013 , No. 35 "On draft law "On nation's participation in change of legal means of payment in the Republic of Latvia" submitted by association "Latviešu Biedrïba”". Available at: https://www.cvk.lv/pub/upload file/35 pilnais.pdf [last viewed September 11, 2019]. Decision No. 17 by CEC of 14.05.2013. On the draft law "Amendment to the Constitution of the Republic of Latvia" submitted by the association "Par latu, pret eiro". Available at: https://www.cvk.lv/pub/upload_file/17_pilnais.pdf [last viewed September 11, 2019].

10. Decision by CEC of 18.03.2013, No. 14 "On draft law "Amendments to the Law On the Bank of Latvia" submitted by the initiative group”. Available at: https://www.cvk.lv/pub/upload_ file/14_pilnais.pdf [last viewed September 11, 2019].

11. Decision by CEC of 31.01.2013, No. 5 "On draft law "On nation's participation in decision making concerning a term of introduction of euro currency" submitted by the initiative group". Available at: https://www.cvk.lv/pub/upload_file/PV\%202013/31012013_CVK_ lemums_Nr_5_izversts.pdf. [last viewed September 11, 2019].

\section{Other sources}

1. Letter by the Saeima Legal Bureau No. 12/13-3-n/36-11/12 to the Central Election Commission. Jurista Vārds, No. 40 (739), 02.10.2012.

2. Initiatives registered for collection of signatures. Available at: https://www.cvk.lv/lv/ iniciativas/veletaju-iniciativas/registretas-iniciativas and https://www.cvk.lv/lv/iniciativas/ veletaju-iniciativas/iniciativas-par-kuram-parakstu-vaksana-noslegusies [last viewed October 28, 2019].

3. Transcript of the $20^{\text {th }}$ sitting of the IV Session of the Constitutional Assembly 09.11.1921. Available at: Latvijas Satversmes Sapulces stenogrammu izvilkums (1920-1922). Riga: Tiesu namu aǵentūra, 2006, p. 467.

4. Letter by the Department of Constitutional and Administrative Law of the Faculty of Law, University of Latvia to CEC, No. 2020-V10-36. Jurista Vārds, No. 40 (739), 02.10.2012, p. 21.

5. Code of Good Practice on Referendums, CDL-AD(2007)008rev, Venice, 16-17 March 2007, point III.3. Available at: http://www.venice.coe.int/webforms/documents/?pdf=CDLAD\% 282007\%29008-e [last viewed September 25, 2019]. 